\title{
CLINICAL EXPERIENCE WITH INTRA-UTERINE DEVICES: PREGNANCIES, EXPULSIONS AND REMOVALS
}

\author{
GHRISTOPHER TIETZE AND SARAH LEWIT \\ Bio-Medical Division, The Population Council, New York
}

(Received 15th December 1967)

\begin{abstract}
Summary. Clinical experience, mostly in the United States, with five major types of intra-uterine devices, computed under the Cooperative Statistical Program of the Population Council, covered 27,575 women with 477,157 months of use as of mid-1967. The devices studied were: the loop, spiral, bow, stainless steel ring and the double coil. The principal reasons for discontinuation of use were removals for bleeding or pain, and expulsion, with the highest risk in the lst year of use. Declines in expulsions and pregnancies were more closely associated with increasing age than with parity, while removal rates declined moderately with increasing parity.
\end{abstract}

The data presented in this report cover clinical experience with intra-uterine devices (IUDs), largely in the United States, for 27,575 women with an aggregate of 477,157 woman-months of use. The statistics are based on individual case records submitted to the Cooperative Statistical Program for the Evaluation of Intra-uterine Devices (CSP) by thirty investigators, twenty-six institutional and four in private practice, over a 4-year period, from July 1963 to June 1967.

The CSP was initiated in mid-1963 by the National Committee on Maternal Health at the request and with the financial assistance of the Population Council. On 1st January 1967 the functions of the National Committee on Maternal Health were transferred to the Council's Bio-Medical Division, under whose auspices the operation of the CSP continues.

Five major types of IUDs in ten sizes are being studied in the CSP: the Lippes loop in four sizes, A, B, C and D, from smallest to largest; the Margulies spiral (Gynekoil) and Birnberg bow, in two sizes each; and the stainless steel ring of Hall and Stone and the double coil (Saf-T-Coil) in a single size. The larger loops (C and particularly D) were the most frequently used devices, accounting for $46 \%$ of all insertions (Table 2). Loop D was the only device for which sufficient data were available for tabulations involving extended durations, annual rates and detailed cross-tabulations (Tables 7 and 9). A residual group of 'other devices' (Tables 2 to 4 ) includes experimental models abandoned after a period of trial and new devices recently added to the programme. 
As shown in Table 1, two out of three women were under 30 years of age at the time of their first insertion, and most of the remaining third were under 40 years. The overwhelming majority $(97 \%)$ had given birth to one or more children, with an average of 3.1 live births per mother.

The number of first insertions and re-insertions and aggregate womanmonths of use are presented in Table 2. Of the 27,575 women with first insertions, 22,230 had one insertion only and 5245 women had at least two insertions. The 6756 re-insertions represented 4192 cases with two insertions, 773 cases with three insertions and 280 cases with four or more insertions.

TABLE 1

NUMBER OF WOMEN BY AGE AND PARITY AT FIRST INSERTION

\begin{tabular}{c|c|c|c}
\hline $\begin{array}{c}\text { Age } \\
\text { (years) }\end{array}$ & Number & Parity & Number \\
\hline $15-19$ & 2,552 & 0 & 910 \\
$20-24$ & 8,830 & 1 & 5,088 \\
$25-29$ & 7,620 & 2 & 7,283 \\
$30-34$ & 4,799 & 3 & 5,566 \\
$35-39$ & 2,608 & 4 & 3,704 \\
$40-44$ & 993 & 5 & 2,077 \\
$45-49$ & 173 & 6 or more & 2,947 \\
\hline Total & 27,575 & & 27,575 \\
\hline
\end{tabular}

TABLE 2

FIRST INSERTIONS AND RE-INSERTIONS AND WOMANMONTHS OF USE, BY TYPE AND SIZE OF DEVICE

\begin{tabular}{|c|c|c|c|c|}
\hline \multirow{2}{*}{ Device } & \multicolumn{3}{|c|}{ Insertions } & \multirow{2}{*}{$\begin{array}{l}\text { Woman- } \\
\text { months } \\
\text { of use }\end{array}$} \\
\hline & First & Later & Total & \\
\hline $\begin{array}{l}\text { Loop A } \\
\text { Loop B } \\
\text { Loop C } \\
\text { Loop D } \\
\text { Small spiral } \\
\text { Large spiral } \\
\text { Small bow } \\
\text { Large bow } \\
\text { Steel ring } \\
\text { Double coil } \\
\text { Other }\end{array}$ & $\begin{array}{r}1,022 \\
1,361 \\
3,858 \\
8,305 \\
452 \\
2,223 \\
1,482 \\
2,276 \\
1,739 \\
2,804 \\
2,053\end{array}$ & $\begin{array}{r}265 \\
128 \\
1,306 \\
2,413 \\
98 \\
313 \\
172 \\
659 \\
376 \\
321 \\
705\end{array}$ & $\begin{array}{r}1,287 \\
1,489 \\
5,164 \\
10,718 \\
550 \\
2,536 \\
1,654 \\
2,935 \\
2,115 \\
3,125 \\
2,758\end{array}$ & $\begin{array}{r}22,367 \\
13,896 \\
67,485 \\
170,858 \\
7,663 \\
39,010 \\
22,540 \\
52,769 \\
38,134 \\
14,586 \\
27,849\end{array}$ \\
\hline Total & 27,575 & 6,756 & 34,331 & 477,157 \\
\hline
\end{tabular}

Of the 27,575 women in the CSP, 11,520 were classified as active users as of 30 th June 1967, of whom one out of two had more than 2 years of experience; 3603 had been released from observation as users at earlier dates; and 12,452 were classified as non-users or inactive cases. Of the last group, 8723 were closed because of pregnancy, expulsion, or removal of the IUD, and 3729 were lost to follow-up. 
Numbers of events and closures

Numbers of events (pregnancies, expulsions, removals), by type and size of IUD, are shown in Table 3. Removals for medical reasons (5353) accounted for more than one third of all events $(15,479)$. Bleeding or pain, often reported together (3942), was the most frequent cause for removal of the IUD. Other medical reasons for removal (1411) cover a miscellany of complaints, some of which are not related to the device.

The second most frequently reported event was expulsion (4818). Complete expulsion into or from the vagina made up $85 \%$ of the reported expulsions; an additional $15 \%$ were partially or completely in the cervical canal and had to be removed. About $80 \%$ of the expulsions were noted by the women and $20 \%$ were unnoticed.

TABLE 3

EVENTS BY TYPE OF TERMINATION, BY TYPE AND SIZE OF DEVICE

\begin{tabular}{|c|c|c|c|c|c|c|c|c|}
\hline \multirow[b]{2}{*}{ Device } & \multirow[b]{2}{*}{ Pregnancies } & \multirow[b]{2}{*}{ Expulsions } & \multicolumn{5}{|c|}{ Reasons for removals } & \multirow[b]{2}{*}{ All events } \\
\hline & & & $\begin{array}{c}\text { Bleeding } \\
\text { andlor } \\
\text { pain }\end{array}$ & $\begin{array}{l}\text { Other } \\
\text { medical }\end{array}$ & $\begin{array}{l}\text { Planning } \\
\text { pregnancy }\end{array}$ & $\begin{array}{c}\text { Other } \\
\text { personal }\end{array}$ & $\begin{array}{l}\text { Investi- } \\
\text { gator's } \\
\text { choice }\end{array}$ & \\
\hline $\begin{array}{l}\text { Loop A } \\
\text { Loop B } \\
\text { Loop C } \\
\text { Loop D } \\
\text { Small spiral } \\
\text { Large spiral } \\
\text { Small bow } \\
\text { Large bow } \\
\text { Steel ring } \\
\text { Double coil } \\
\text { Other }\end{array}$ & $\begin{array}{r}93 \\
39 \\
143 \\
332 \\
23 \\
48 \\
192 \\
197 \\
141 \\
36 \\
92\end{array}$ & $\begin{array}{r}255 \\
225 \\
897 \\
1,414 \\
174 \\
605 \\
74 \\
83 \\
353 \\
362 \\
376\end{array}$ & $\begin{array}{r}128 \\
144 \\
552 \\
1,447 \\
53 \\
429 \\
182 \\
407 \\
183 \\
214 \\
203\end{array}$ & $\begin{array}{r}66 \\
54 \\
182 \\
462 \\
23 \\
250 \\
49 \\
148 \\
58 \\
56 \\
63\end{array}$ & $\begin{array}{r}49 \\
13 \\
111 \\
287 \\
24 \\
75 \\
43 \\
84 \\
91 \\
7 \\
52\end{array}$ & $\begin{array}{r}63 \\
34 \\
117 \\
335 \\
54 \\
119 \\
74 \\
96 \\
60 \\
27 \\
77\end{array}$ & $\begin{array}{r}340 \\
10 \\
20 \\
121 \\
11 \\
40 \\
775 \\
176 \\
32 \\
8 \\
547\end{array}$ & $\begin{array}{r}994 \\
519 \\
2,022 \\
4,398 \\
362 \\
1,566 \\
1,389 \\
1,191 \\
918 \\
710 \\
1,410\end{array}$ \\
\hline Total & 1,336 & 4,818 & 3,942 & 1,411 & 836 & 1,056 & 2,080 & 15,479 \\
\hline
\end{tabular}

Investigator's choice (2080) covers, mainly, removals involving research procedures or the replacement of a device by another considered more effective. Removals for personal reasons (1892) include 836 for planning pregnancy and 1056 for other personal reasons, including fear, lack of confidence, objection of husband or of family physician, separation from husband, and similar reasons.

Of the 1336 pregnancies reported, two out of three occurred with the IUD in situ, and the remaining one third with the position of the device at the time of conception undetermined.

Closures because of pregnancy, expulsion or removal, by type and size of device, are shown in Table 4. The numbers of closures are smaller than the numbers of corresponding events (Table 3), especially for removals at the investigator's choice and for expulsions, because many events were followed by re-insertions. One out of two closed cases was terminated for medical reasons; one out of five, for expulsion; and about one in eight, for pregnancy. 
TABLE 4

GLOSURES BY TYPE OF TERMINATION, BY TYPE AND SIZE OF DEVIGE

\begin{tabular}{|c|c|c|c|c|c|c|c|c|}
\hline \multirow[b]{2}{*}{ Device } & \multirow[b]{2}{*}{ Pregnancies } & \multirow[b]{2}{*}{ Expulsions } & \multicolumn{5}{|c|}{ Reasons for removals } & \multirow[b]{2}{*}{ All events } \\
\hline & & & $\begin{array}{l}\text { Bleeding } \\
\text { and/or } \\
\text { pain }\end{array}$ & $\begin{array}{c}\text { Other } \\
\text { medical }\end{array}$ & $\begin{array}{l}\text { Planning } \\
\text { pregnancy }\end{array}$ & $\begin{array}{c}\text { Other } \\
\text { personal }\end{array}$ & $\begin{array}{l}\text { Investi- } \\
\text { gator's } \\
\text { choice }\end{array}$ & \\
\hline $\begin{array}{l}\text { Loop A } \\
\text { Loop B } \\
\text { Loop G } \\
\text { Loop D } \\
\text { Small spiral } \\
\text { Large spiral } \\
\text { Small bow } \\
\text { Large bow } \\
\text { Steel ring } \\
\text { Double coil } \\
\text { Other }\end{array}$ & $\begin{array}{r}76 \\
36 \\
127 \\
285 \\
16 \\
39 \\
158 \\
160 \\
126 \\
34 \\
73\end{array}$ & $\begin{array}{r}84 \\
69 \\
285 \\
487 \\
53 \\
192 \\
17 \\
38 \\
121 \\
140 \\
148\end{array}$ & $\begin{array}{r}85 \\
135 \\
496 \\
1,275 \\
36 \\
280 \\
110 \\
343 \\
154 \\
205 \\
162\end{array}$ & $\begin{array}{r}36 \\
42 \\
141 \\
331 \\
17 \\
131 \\
35 \\
121 \\
52 \\
52 \\
47\end{array}$ & $\begin{array}{r}32 \\
13 \\
95 \\
227 \\
18 \\
62 \\
33 \\
67 \\
71 \\
7 \\
38\end{array}$ & $\begin{array}{r}52 \\
32 \\
109 \\
301 \\
45 \\
95 \\
64 \\
82 \\
56 \\
27 \\
67\end{array}$ & $\begin{array}{r}6 \\
1 \\
4 \\
21 \\
2 \\
4 \\
9 \\
18 \\
10 \\
1 \\
4\end{array}$ & $\begin{array}{r}371 \\
328 \\
1,257 \\
2,927 \\
187 \\
803 \\
426 \\
829 \\
590 \\
466 \\
539\end{array}$ \\
\hline Total & 1,130 & 1,634 & 3,281 & 1,005 & 663 & 930 & 80 & 8,723 \\
\hline
\end{tabular}

\section{Event rates and closure rates}

All of the rates shown in this report are net rates of events and closures computed by means of multiple decrement life table procedures. The application of life table methods to contraceptive behaviour was developed jointly by Robert G. Potter and the senior author (G.T.) in the United States, and independently by Benjamin Viel in Chile.

The great majority of the rates shown here is based on the entire experience with each type and size of IUD following first and later insertions; one table is limited to experience following first insertions only (Table 10), and one table to later insertions only (Table 11 ). In all tables, the notation 0.0 indicates a rate of less than 0.05 , including a zero rate. Rates based on less than 1200 woman-months of use are not shown. Insertions during the first 4 weeks after a delivery or abortion are excluded from all tables except Table 10 and nulliparous women are excluded from Tables 8 to 10 (Potter, 1963, 1966, 1967; Tietze, 1965, 1967; Viel, 1966).

Cumulative event and closure rates by type and size of device and type of termination, after 1 year of use and after 2 years, are shown in Tables 5 and 6 . Closure rates are consistently lower than event rates because, as has been stated, there are fewer closures than events. For instance, by the end of the 2nd year, $11.5 \%$ of all women wearing Loop D had experienced a first expulsion, but only $3.6 \%$ had discontinued its use for this reason. By subtracting the closures $(3.6 \%)$ from the events $(11.5 \%)$ it can be seen that $7.9 \%$ of the women wearing Loop D (more than two out of three women with a first expulsion) had the loop re-inserted after a first expulsion. Since only $2.3 \%$ of all cases were closed after a later expulsion, it follows that $5.6 \%$ of the women, or one half of those with a first expulsion, continued to wear the loop after one or more re-insertions for at least 2 years after the first insertion.

At the end of the 2-year period, as well as after 1 year, pregnancy rates and expulsion rates were higher for the smaller devices than for the larger ones of 


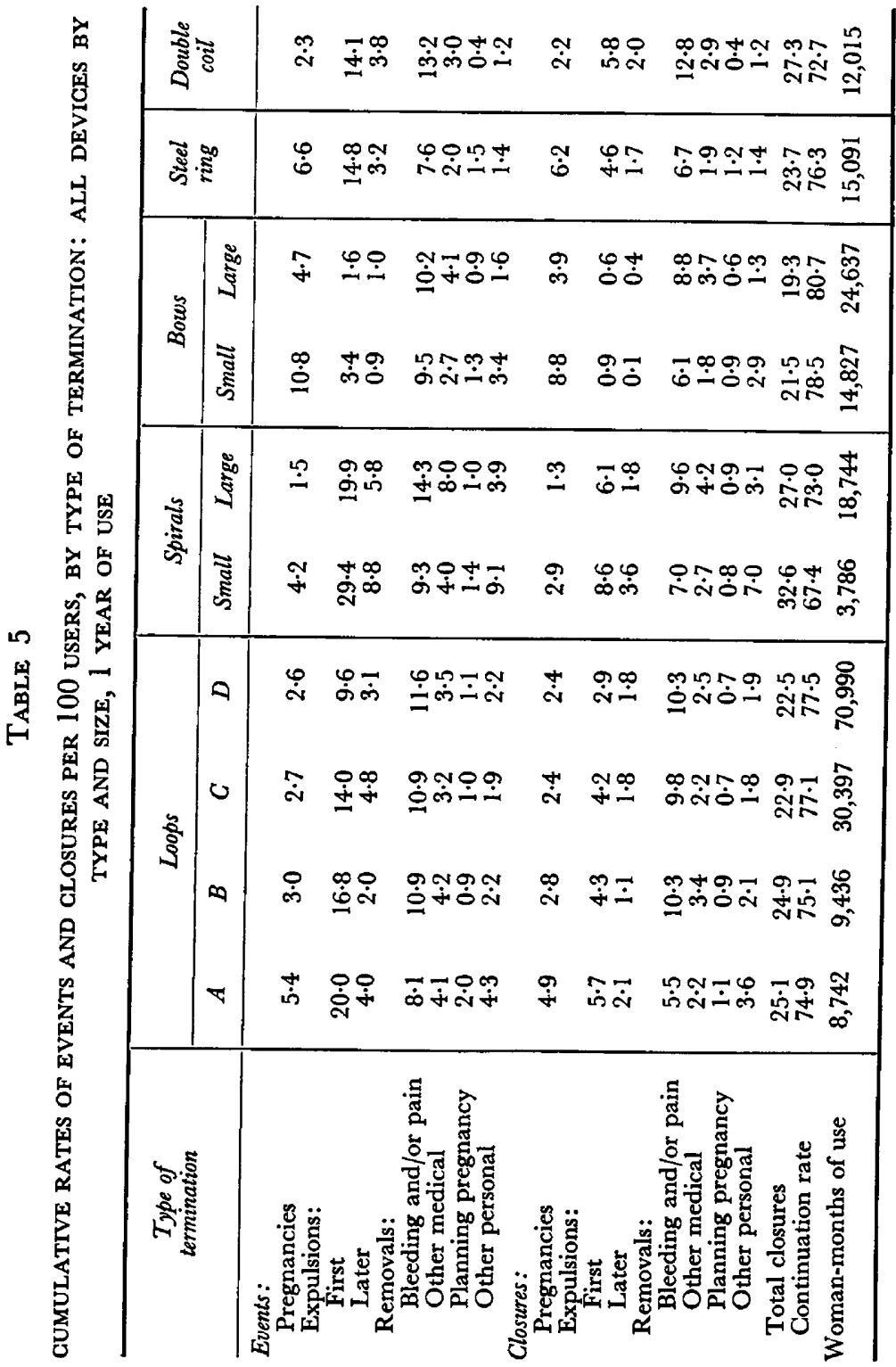




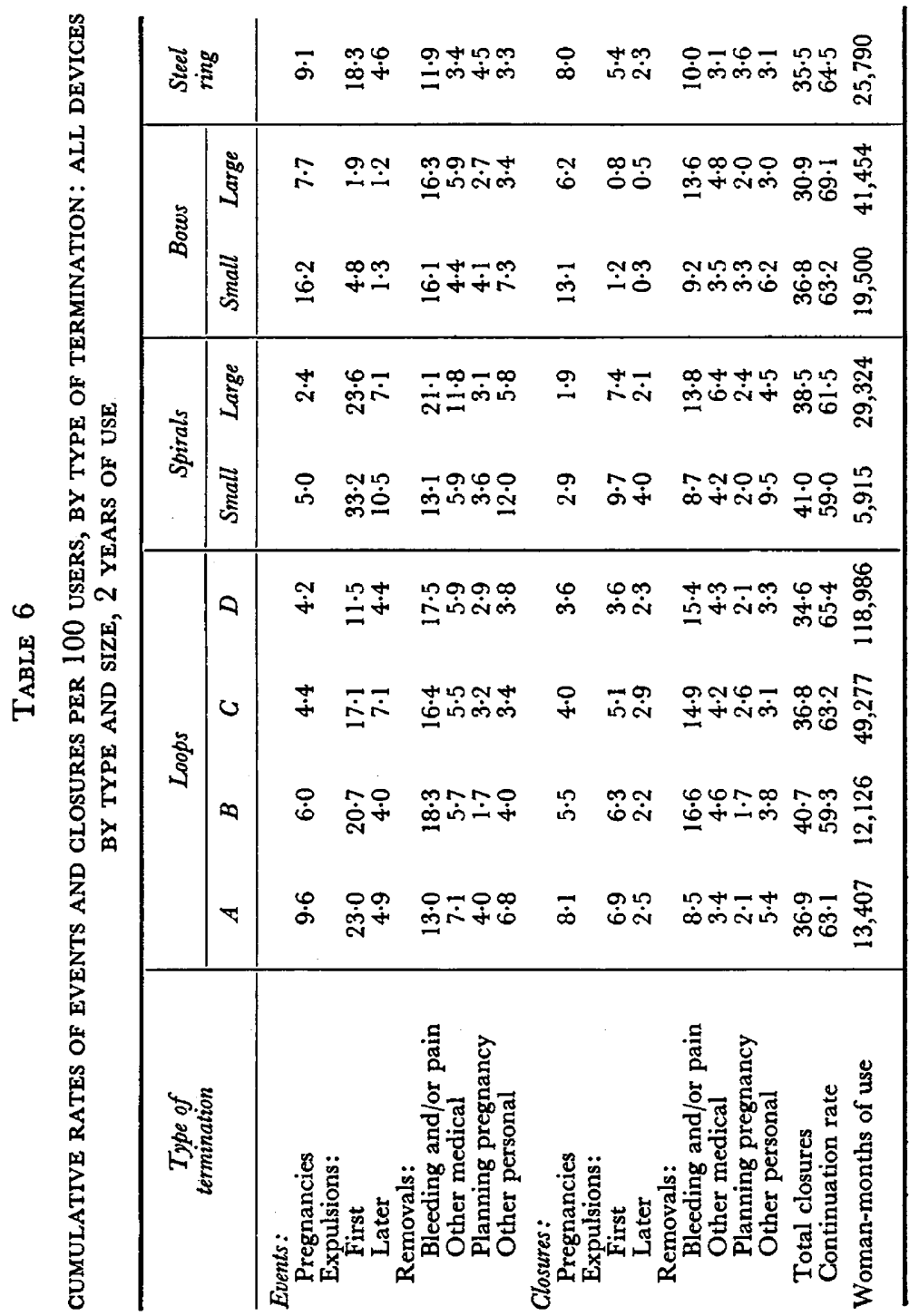


the same type, while removal rates were not significantly associated with size of device, except for the spiral. The experience with the smaller devices has resulted in a general limitation of their use to nulliparous women only. Among the larger IUDs, and those of a single size, the spiral had the lowest pregnancy rate, followed by the double coil and the loop, and the steel ring and the bow had the highest. The expulsion rate was lowest for the bow, followed by the loop (Loop D) and, at some distance, by the double coil and steel ring. The spiral had the highest expulsion rate. The steel ring had the lowest removal rate for medical reasons, followed by the bow, loop and double coil; the spiral had the highest. Continuation rates were quite similar for the various devices with about two out of three women remaining users at the end of the 2-year period.

Annual and cumulative rates of events and closures for a period of 5 years by type of termination are shown for Loop D in Table 7. The annual rates per 100 users at the beginning of each year decreased with each year of use for most events and closures, especially for such major reasons for termination as expulsions and removals for medical reasons, while the rates of removal for planning pregnancy increased through the 4 th year. The result was that annual closure rates declined each year; from $22.5 \%$ for the 1st year to $7 \cdot 1 \%$ for the 5 th year. The cumulative closure rates, up to the end of each successive anniversary of first insertion increased from $22.5 \%$ for the 1st year to $53.9 \%$ for the 5th year; and its complement, the continuation rate, declined from $77.5 \%$ to $46 \cdot 1 \%$ over the same period of time.

\section{Age and parity}

Cumulative rates of events by age and parity of women at first insertion are shown in Table 8 for a 2-year period for five major devices: Loops $\mathrm{C}$ and D, the large spiral, the large bow and the steel ring. Expulsion rates and, to some extent, removal rates tended to decline for each device with both age at insertion and with parity. Some decline in pregnancy rates was observed with age, as might be expected, but no association was observed with parity. Closure rates declined sharply with increasing age at insertion for each device, and almost as sharply with increasing parity. About three out of four older women and women of high parity were continuing users after 2 years compared with about one out of two of the young women and of those of low parity.

In spite of the large differences in expulsion rates between younger women and older women, standardization for age had little effect on the levels of the rates for each type and size of IUD, because the age distribution of the women was quite similar between devices. The following figures show cumulative event rates of first expulsion at the end of 1 year and after 2 years, adjusted for age, which can be compared with the rates in Tables 5 and 6 .

$\begin{array}{lcc}\quad \text { Device } & \text { 1st year } & \text { 2nd year } \\ \text { Loop C } & 14.5 & 17.7 \\ \text { Loop D } & 10.0 & 11.9 \\ \text { Large spiral } & 21.5 & 25.5 \\ \text { Large bow } & 1.6 & 1.9 \\ \text { Steel ring } & 15.5 & 19.0 \\ \text { Double coil } & 13.5 & -\end{array}$




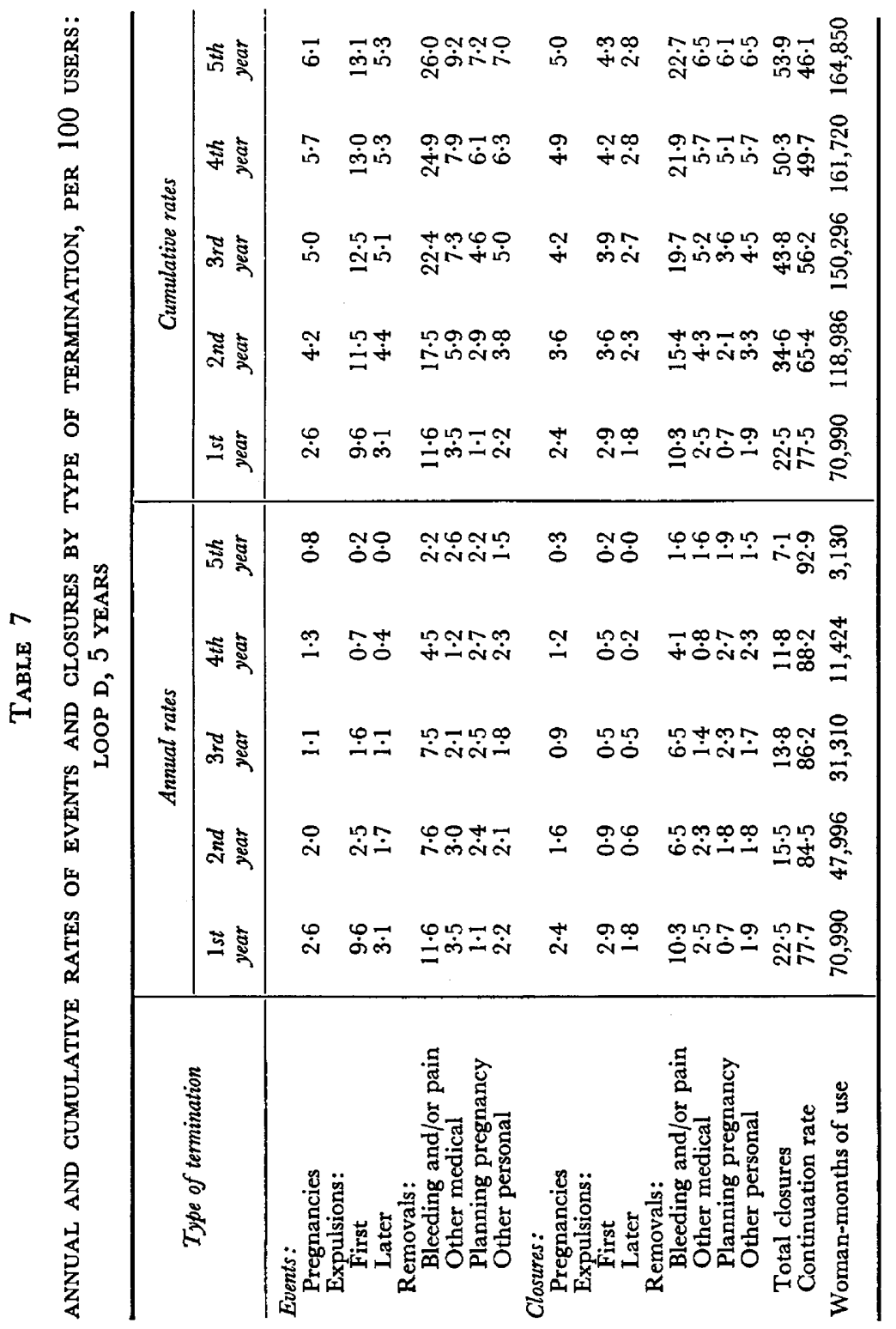


A cross-tabulation by age by parity after 2 years of use for Loop D is shown in Table 9. Pregnancy rates declined sharply with age within each parity group and increased somewhat with prior parity within most age groups. A well-defined decline in expulsion rates was noted with age within each parity group and some decline with parity at the younger ages. Removal rates declined moderately with parity within each age group and showed no association with age within parity. All in all, age emerged as a more important factor than parity.

\section{Interval since last confinement}

Cumulative rates of events by type of termination by interval between first insertion and most recent confinement are shown for Loops $C$ and $D$, the large spiral, the large bow and the steel ring in Table 10. Expulsion rates were highest for insertions during the early post partum period (first 10 days); this information is available for the loops only. For all devices, expulsion rates were slightly higher for insertions during the late post partum period (5 to 12 weeks), than after 3 months post partum. Pregnancy rates and removal rates were not significantly associated with the interval between insertion and confinement.

\section{Re-insertions}

Net cumulative rates of termination at the end of 2 years are shown separately per 100 first re-insertions following expulsion and those following removal for selected devices (Table 11). The expulsion rate was much higher for women who had experienced a previous one than for women with no previous expulsion. Expulsion rates following removal were quite low. About two out of five women with a previous expulsion retained the device for at least 2 years after re-insertion. For each device, there was little difference between the removal or

TABLE 8

CUMULATIVE RATES OF EVENTS BY TYPE OF TERMINATION AND OF GLOSURES, PER 100 USERS, BY AGE AND BY PARITY AT FIRST INSERTION: SELECTED DEVICES, 2 YEARS OF USE

\begin{tabular}{|c|c|c|c|c|c|c|c|}
\hline \multirow{2}{*}{$\begin{array}{l}\text { Termination of events } \\
\text { and total closures }\end{array}$} & \multicolumn{4}{|c|}{ Age at insertion } & \multicolumn{3}{|c|}{ Parity } \\
\hline & 15 to 24 & 25 to 29 & 30 to 34 & 35 to 49 & 1 or 2 & 3 or 4 & 5 or more \\
\hline $\begin{array}{l}\text { Loop } C \\
\text { Pregnancies } \\
\text { Expulsions: }\end{array}$ & $5 \cdot 6$ & $4 \cdot 9$ & $4 \cdot 1$ & $1 \cdot 3$ & $5 \cdot 3$ & $3 \cdot 9$ & $3 \cdot 5$ \\
\hline $\begin{array}{l}\text { First } \\
\text { Later }\end{array}$ & $\begin{array}{l}25 \cdot 4 \\
12 \cdot 3\end{array}$ & $\begin{array}{r}15 \cdot 9 \\
6 \cdot 1\end{array}$ & $\begin{array}{r}11 \cdot 1 \\
3 \cdot 3\end{array}$ & $\begin{array}{l}6 \cdot 4 \\
1 \cdot 2\end{array}$ & $\begin{array}{r}20 \cdot 9 \\
9 \cdot 0\end{array}$ & $\begin{array}{r}14 \cdot 8 \\
6 \cdot 4\end{array}$ & $\begin{array}{r}12 \cdot 2 \\
4 \cdot 3\end{array}$ \\
\hline $\begin{array}{l}\text { Removals: } \\
\text { Bleeding and/or pain } \\
\text { Other medical } \\
\text { Planning pregnancy } \\
\text { Other personal }\end{array}$ & $\begin{array}{r}18 \cdot 8 \\
6 \cdot 3 \\
5 \cdot 4 \\
4 \cdot 0\end{array}$ & $\begin{array}{r}15 \cdot 4 \\
6 \cdot 3 \\
2 \cdot 9 \\
2 \cdot 5\end{array}$ & $\begin{array}{r}15 \cdot 1 \\
4 \cdot 6 \\
1 \cdot 0 \\
3 \cdot 9\end{array}$ & $\begin{array}{r}12 \cdot 8 \\
4 \cdot 1 \\
0 \cdot 2 \\
2 \cdot 0\end{array}$ & $\begin{array}{r}20 \cdot 1 \\
5 \cdot 4 \\
5 \cdot 9 \\
3 \cdot 9\end{array}$ & $\begin{array}{r}14 \cdot 8 \\
6 \cdot 0 \\
0 \cdot 9 \\
3 \cdot 0\end{array}$ & $\begin{array}{l}9 \cdot 4 \\
5 \cdot 6 \\
0 \cdot 7 \\
2 \cdot 0\end{array}$ \\
\hline $\begin{array}{l}\text { Total closures } \\
\text { Continuation rate }\end{array}$ & $\begin{array}{l}47 \cdot 4 \\
52 \cdot 6\end{array}$ & $\begin{array}{l}34 \cdot 9 \\
65 \cdot 1\end{array}$ & $\begin{array}{l}30 \cdot 4 \\
69 \cdot 6\end{array}$ & $\begin{array}{l}20 \cdot 1 \\
79 \cdot 9\end{array}$ & $\begin{array}{l}45 \cdot 9 \\
54 \cdot 1\end{array}$ & $\begin{array}{l}31 \cdot 6 \\
68 \cdot 4\end{array}$ & $\begin{array}{l}23 \cdot 2 \\
76 \cdot 8\end{array}$ \\
\hline Woman-months of use & 17,121 & 13,945 & 8,801 & 8,723 & 20,570 & 18,456 & 9,564 \\
\hline
\end{tabular}


TABLE 8 (continued)

\begin{tabular}{|c|c|c|c|c|c|c|c|}
\hline \multirow{2}{*}{$\begin{array}{l}\text { Termination of events } \\
\text { and total closures }\end{array}$} & \multicolumn{4}{|c|}{ Age at insertion } & \multicolumn{3}{|c|}{ Parity } \\
\hline & 15 to 24 & 25 to 29 & 30 to 34 & 35 to 49 & 1 or 2 & 3 or 4 & 5 or more \\
\hline $\begin{array}{l}\text { Loop } D \\
\text { Pregnancies } \\
\text { Expulsions: }\end{array}$ & $5 \cdot 7$ & $4 \cdot 7$ & $2 \cdot 9$ & $1 \cdot 6$ & $4 \cdot 4$ & $4 \cdot 2$ & $3 \cdot 9$ \\
\hline $\begin{array}{l}\text { First } \\
\text { Later }\end{array}$ & $\begin{array}{r}17 \cdot 4 \\
7 \cdot 5\end{array}$ & $\begin{array}{l}9 \cdot 9 \\
4 \cdot 1\end{array}$ & $\begin{array}{l}7 \cdot 1 \\
2 \cdot 3\end{array}$ & $\begin{array}{l}5 \cdot 4 \\
0.7\end{array}$ & $\begin{array}{r}14 \cdot 4 \\
5 \cdot 6\end{array}$ & $\begin{array}{r}10 \cdot 2 \\
4 \cdot 2\end{array}$ & $\begin{array}{l}7 \cdot 2 \\
2 \cdot 3\end{array}$ \\
\hline $\begin{array}{l}\text { Removals: } \\
\text { Bleeding and/or pain } \\
\text { Other medical } \\
\text { Planning pregnancy } \\
\text { Other personal }\end{array}$ & $\begin{array}{r}18 \cdot 0 \\
6 \cdot 6 \\
5 \cdot 0 \\
4 \cdot 7\end{array}$ & $\begin{array}{r}17 \cdot 5 \\
5 \cdot 7 \\
2 \cdot 7 \\
3 \cdot 6\end{array}$ & $\begin{array}{r}16 \cdot 7 \\
4 \cdot 8 \\
1 \cdot 0 \\
3 \cdot 5\end{array}$ & $\begin{array}{r}16 \cdot 6 \\
5 \cdot 6 \\
0 \cdot 6 \\
2 \cdot 5\end{array}$ & $\begin{array}{r}19 \cdot 5 \\
5 \cdot 9 \\
5 \cdot 4 \\
3 \cdot 9\end{array}$ & $\begin{array}{r}16.9 \\
6.1 \\
1.5 \\
3.5\end{array}$ & $\begin{array}{r}13 \cdot 6 \\
5 \cdot 4 \\
0 \cdot 4 \\
4 \cdot 5\end{array}$ \\
\hline $\begin{array}{l}\text { Total closures } \\
\text { Continuation rate }\end{array}$ & $\begin{array}{l}42 \cdot 3 \\
57 \cdot 7\end{array}$ & $\begin{array}{l}33 \cdot 1 \\
66 \cdot 9\end{array}$ & $\begin{array}{l}28 \cdot 4 \\
71 \cdot 6\end{array}$ & $\begin{array}{l}25 \cdot 4 \\
74 \cdot 6\end{array}$ & $\begin{array}{l}40 \cdot 8 \\
59 \cdot 2\end{array}$ & $\begin{array}{l}31 \cdot 3 \\
68 \cdot 7\end{array}$ & $\begin{array}{l}26 \cdot 1 \\
73 \cdot 9\end{array}$ \\
\hline Woman-months of use & 40,885 & 33,815 & 23,558 & 19,372 & 48,046 & 45,060 & 24,524 \\
\hline $\begin{array}{l}\text { Large spiral } \\
\text { Pregnancies } \\
\text { Expulsions: }\end{array}$ & $2 \cdot 3$ & $3 \cdot 0$ & 1.8 & $2 \cdot 0$ & $1 \cdot 7$ & $2 \cdot 7$ & $2 \cdot 7$ \\
\hline $\begin{array}{l}\text { First } \\
\text { Later }\end{array}$ & $\begin{array}{l}33 \cdot 9 \\
10 \cdot 8\end{array}$ & $\begin{array}{r}23 \cdot 4 \\
6 \cdot 2\end{array}$ & $\begin{array}{r}21 \cdot 5 \\
5 \cdot 5\end{array}$ & $\begin{array}{l}9 \cdot 3 \\
3 \cdot 1\end{array}$ & $\begin{array}{r}26 \cdot 0 \\
7 \cdot 9\end{array}$ & $\begin{array}{r}22 \cdot 7 \\
7 \cdot 2\end{array}$ & $\begin{array}{r}21 \cdot 5 \\
5 \cdot 3\end{array}$ \\
\hline $\begin{array}{l}\text { Removals: } \\
\text { Bleeding and/or pain } \\
\text { Other medical } \\
\text { Planning pregnancy } \\
\text { Other personal }\end{array}$ & $\begin{array}{r}23 \cdot 6 \\
12 \cdot 1 \\
4 \cdot 4 \\
8 \cdot 8\end{array}$ & $\begin{array}{r}21 \cdot 4 \\
12 \cdot 6 \\
3 \cdot 5 \\
4 \cdot 9\end{array}$ & $\begin{array}{r}21 \cdot 4 \\
11 \cdot 4 \\
2 \cdot 6 \\
5 \cdot 2\end{array}$ & $\begin{array}{r}16 \cdot 3 \\
10 \cdot 9 \\
0 \cdot 7 \\
2 \cdot 9\end{array}$ & $\begin{array}{r}25 \cdot 6 \\
13 \cdot 1 \\
6 \cdot 3 \\
6 \cdot 6\end{array}$ & $\begin{array}{r}22 \cdot 1 \\
10 \cdot 0 \\
1 \cdot 4 \\
5 \cdot 2\end{array}$ & $\begin{array}{r}13 \cdot 2 \\
12 \cdot 0 \\
0.7 \\
5.3\end{array}$ \\
\hline $\begin{array}{l}\text { Total closures } \\
\text { Continuation rate }\end{array}$ & $\begin{array}{l}47 \cdot 1 \\
52 \cdot 9\end{array}$ & $\begin{array}{l}37 \cdot 9 \\
62 \cdot 1\end{array}$ & $\begin{array}{l}34 \cdot 9 \\
65 \cdot 1\end{array}$ & $\begin{array}{l}29 \cdot 3 \\
70 \cdot 7\end{array}$ & $\begin{array}{l}45 \cdot 9 \\
54 \cdot 1\end{array}$ & $\begin{array}{l}36 \cdot 5 \\
63 \cdot 5\end{array}$ & $\begin{array}{l}30 \cdot 6 \\
69 \cdot 4\end{array}$ \\
\hline Woman-months of use & 8,172 & 7,996 & 6,736 & 5,572 & 10,550 & 9,836 & 8,090 \\
\hline $\begin{array}{l}\text { Large bow } \\
\text { Pregnancies } \\
\text { Expulsions: }\end{array}$ & $8 \cdot 4$ & $8 \cdot 2$ & $6 \cdot 2$ & $6 \cdot 2$ & $8 \cdot 2$ & $6 \cdot 8$ & $8 \cdot 5$ \\
\hline $\begin{array}{l}\text { Expuissions: } \\
\text { First } \\
\text { Later }\end{array}$ & $\begin{array}{l}2 \cdot 2 \\
1 \cdot 9\end{array}$ & $\begin{array}{l}0 \cdot 8 \\
0 \cdot 6\end{array}$ & $\begin{array}{l}3 \cdot 0 \\
1 \cdot 1\end{array}$ & $\begin{array}{l}1 \cdot 7 \\
0.0\end{array}$ & $\begin{array}{l}2 \cdot 7 \\
1 \cdot 3\end{array}$ & $\begin{array}{l}1 \cdot 3 \\
1 \cdot 2\end{array}$ & $\begin{array}{l}1 \cdot 2 \\
1 \cdot 0\end{array}$ \\
\hline $\begin{array}{l}\text { Removals: } \\
\text { Bleeding and/or pain } \\
\text { Other medical } \\
\text { Planning pregnancy } \\
\text { Other personal }\end{array}$ & $\begin{array}{r}19 \cdot 0 \\
6 \cdot 7 \\
3 \cdot 8 \\
3 \cdot 7\end{array}$ & $\begin{array}{r}15 \cdot 6 \\
4 \cdot 8 \\
2 \cdot 2 \\
3 \cdot 3\end{array}$ & $\begin{array}{r}14 \cdot 2 \\
5 \cdot 6 \\
1 \cdot 3 \\
3 \cdot 3\end{array}$ & $\begin{array}{l}9 \cdot 5 \\
5 \cdot 5 \\
1 \cdot 1 \\
2 \cdot 1\end{array}$ & $\begin{array}{r}20 \cdot 0 \\
5 \cdot 7 \\
5 \cdot 0 \\
3 \cdot 5\end{array}$ & $\begin{array}{r}14 \cdot 6 \\
5 \cdot 5 \\
1 \cdot 3 \\
3 \cdot 4\end{array}$ & $\begin{array}{r}12 \cdot 0 \\
7 \cdot 0 \\
0 \cdot 5 \\
3 \cdot 0\end{array}$ \\
\hline $\begin{array}{l}\text { Total closures } \\
\text { Continuation rate }\end{array}$ & $\begin{array}{l}37 \cdot 0 \\
63 \cdot 0\end{array}$ & $\begin{array}{l}27 \cdot 4 \\
72 \cdot 6\end{array}$ & $\begin{array}{l}27 \cdot 5 \\
72 \cdot 5\end{array}$ & $\begin{array}{l}18 \cdot 9 \\
81 \cdot 1\end{array}$ & $\begin{array}{l}37 \cdot 1 \\
62 \cdot 9\end{array}$ & $\begin{array}{l}26 \cdot 6 \\
73 \cdot 4\end{array}$ & $\begin{array}{l}26 \cdot 2 \\
73 \cdot 8\end{array}$ \\
\hline Woman-months of use & 7,1902 & 11,930 & 6,767 & 4,753 & 16,338 & 15,681 & 9,333 \\
\hline $\begin{array}{l}\text { Steel ring } \\
\text { Pregnancies } \\
\text { Expulsions: }\end{array}$ & $12 \cdot 6$ & $8 \cdot 4$ & 6.7 & $4 \cdot 9$ & $10 \cdot 3$ & $9 \cdot 1$ & $7 \cdot 3$ \\
\hline $\begin{array}{l}\text { First } \\
\text { Later }\end{array}$ & $\begin{array}{r}29 \cdot 6 \\
7 \cdot 4\end{array}$ & $\begin{array}{r}14 \cdot 4 \\
3 \cdot 1\end{array}$ & $\begin{array}{l}9 \cdot 5 \\
3 \cdot 5\end{array}$ & $\begin{array}{l}8 \cdot 0 \\
2 \cdot 8\end{array}$ & $\begin{array}{r}25 \cdot 4 \\
6.5\end{array}$ & $\begin{array}{r}13 \cdot 7 \\
3 \cdot 9\end{array}$ & $\begin{array}{l}9 \cdot 1 \\
1 \cdot 4\end{array}$ \\
\hline $\begin{array}{l}\text { Removals: } \\
\text { Bleeding and/or pain } \\
\text { Other medical } \\
\text { Planning pregnancy } \\
\text { Other personal }\end{array}$ & $\begin{array}{r}12 \cdot 8 \\
4 \cdot 5 \\
5 \cdot 2 \\
4 \cdot 1\end{array}$ & $\begin{array}{r}13 \cdot 2 \\
4 \cdot 2 \\
4 \cdot 4 \\
2 \cdot 1\end{array}$ & $\begin{array}{l}9 \cdot 1 \\
1 \cdot 8 \\
2 \cdot 0 \\
3.7\end{array}$ & $\begin{array}{r}13.0 \\
1.9 \\
0.6 \\
2.8\end{array}$ & $\begin{array}{r}12 \cdot 9 \\
3 \cdot 2 \\
6 \cdot 0 \\
2 \cdot 8\end{array}$ & $\begin{array}{r}12.4 \\
3.5 \\
2.2 \\
3.5\end{array}$ & $\begin{array}{r}10.5 \\
5.6 \\
0.0 \\
4.9\end{array}$ \\
\hline $\begin{array}{l}\text { Total closures } \\
\text { Continuation rate }\end{array}$ & $\begin{array}{l}47 \cdot 0 \\
53 \cdot 0\end{array}$ & $\begin{array}{l}34 \cdot 4 \\
65 \cdot 6\end{array}$ & $\begin{array}{l}22 \cdot 6 \\
77 \cdot 4\end{array}$ & $\begin{array}{l}23 \cdot 9 \\
76 \cdot 1\end{array}$ & $\begin{array}{l}41 \cdot 4 \\
58 \cdot 6\end{array}$ & $\begin{array}{l}33 \cdot 5 \\
66 \cdot 5\end{array}$ & $\begin{array}{l}25 \cdot 0 \\
75 \cdot 0\end{array}$ \\
\hline Woman-months of use & 9,121 & 7,114 & 4,551 & 3,111 & 12,043 & 8,131 & 3,713 \\
\hline
\end{tabular}




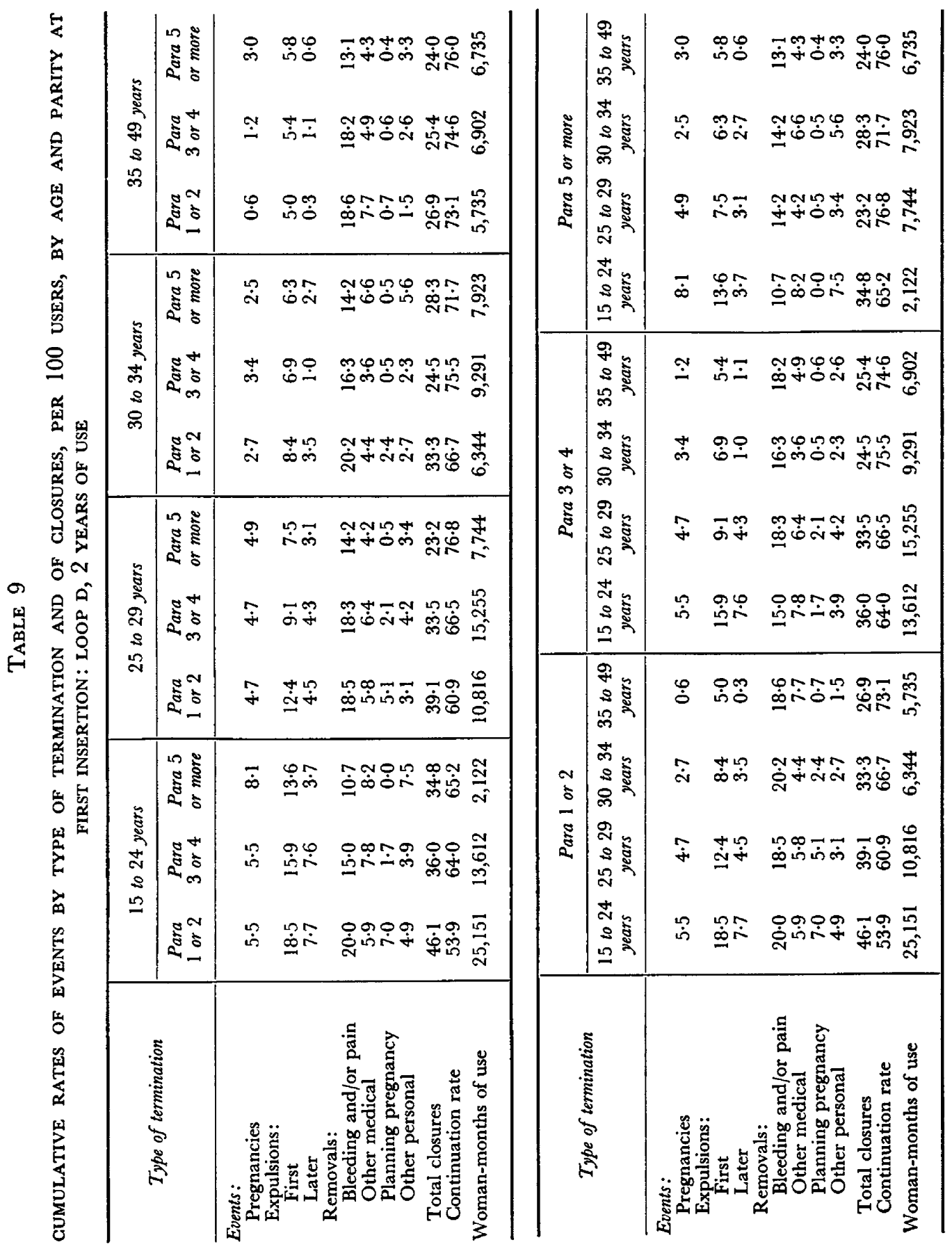


TABLe 10

GUMULATIVE EVENT RATES BY INTERVAL BETWEEN INSERTION AND LAST CONFINEMENT, PER 100 FIRST INSERTIONS: SELEGTED DEVICES, 2 YEARS OF USE

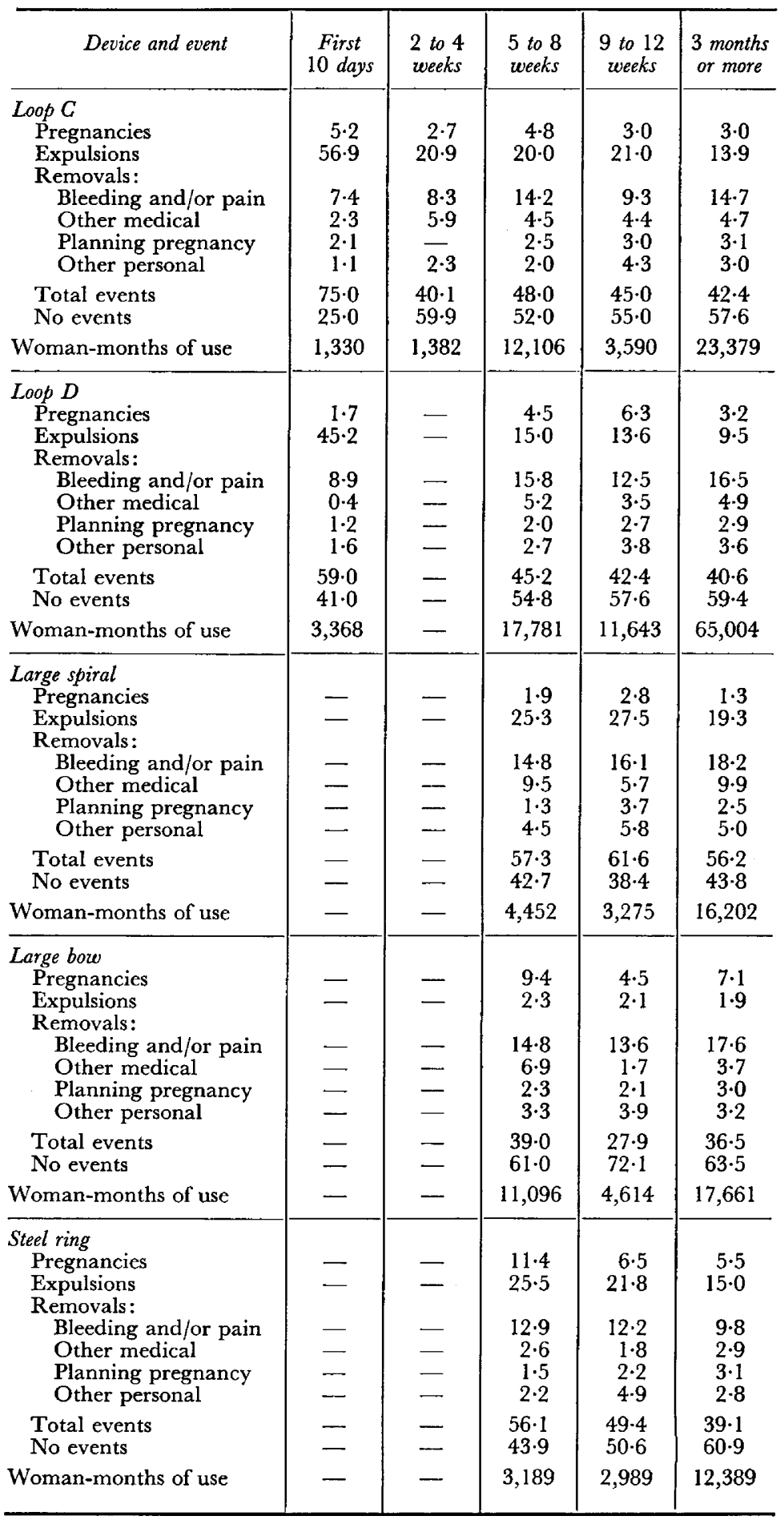


TABLE 11

GUMULATIVE RATES OF EVENTS BY TYPE OF TERMINATION, PER 100 FIRST RE-INSERTIONS, AFTER EXPULSION AND AFTER REMOVAL: SELECTED DEVIGES, 2 YEARS OF USE

\begin{tabular}{l|r|r|r|r|c}
\hline \multicolumn{1}{c|}{ Type of termination } & Loop $C$ & Loop D & $\begin{array}{c}\text { Large } \\
\text { spiral }\end{array}$ & $\begin{array}{c}\text { Large } \\
\text { bow }\end{array}$ & $\begin{array}{c}\text { Steel } \\
\text { ring }\end{array}$ \\
\hline After expulsion: & & & & & \\
Pregnancies & $4 \cdot 2$ & $4 \cdot 8$ & $2 \cdot 5$ & $5 \cdot 7$ & - \\
Expulsions & $41 \cdot 1$ & $33 \cdot 7$ & $58 \cdot 3$ & $9 \cdot 5$ & - \\
Removals: & $10 \cdot 1$ & $11 \cdot 1$ & $9 \cdot 6$ & $12 \cdot 2$ & - \\
$\quad$ Bleeding and/or pain & $1 \cdot 1$ & $3 \cdot 8$ & $4 \cdot 5$ & $6 \cdot 6$ & - \\
Other medical & $0 \cdot 9$ & $3 \cdot 4$ & $2 \cdot 2$ & $1 \cdot 7$ & - \\
$\quad$ Planning pregnancy & $2 \cdot 3$ & $3 \cdot 0$ & $1 \cdot 2$ & $1 \cdot 6$ & - \\
$\quad$ Other personal & $59 \cdot 7$ & $59 \cdot 8$ & $78 \cdot 3$ & $37 \cdot 3$ & - \\
Total events & $40 \cdot 3$ & $40 \cdot 2$ & $21 \cdot 7$ & $62 \cdot 7$ & - \\
No events & 4,239 & 6,972 & 1,348 & 3,322 & - \\
Woman-months of use & & & & & \\
& & & & \\
After removal: & $2 \cdot 6$ & $3 \cdot 1$ & - & $9 \cdot 2$ & $10 \cdot 5$ \\
Pregnancies & $8 \cdot 7$ & $7 \cdot 3$ & - & $0 \cdot 9$ & $13 \cdot 8$ \\
Expulsions & & & & \\
Removals: & $17 \cdot 4$ & $13 \cdot 1$ & - & $12 \cdot 8$ & $15 \cdot 3$ \\
$\quad$ Bleeding and/or pain & $5 \cdot 7$ & $6 \cdot 4$ & - & $8 \cdot 5$ & $4 \cdot 0$ \\
Other medical & $5 \cdot 3$ & $2 \cdot 8$ & - & $5 \cdot 2$ & $1 \cdot 8$ \\
$\quad$ Planning pregnancy & $5 \cdot 0$ & $4 \cdot 3$ & - & $3 \cdot 3$ & $2 \cdot 6$ \\
$\quad$ Other personal & $44 \cdot 7$ & $37 \cdot 0$ & - & $39 \cdot 9$ & $48 \cdot 0$ \\
Total events & $55 \cdot 3$ & $63 \cdot 0$ & - & $60 \cdot 1$ & $52 \cdot 0$ \\
No events & 6,107 & 15,700 & - & $\mathbf{4 , 3 2 3}$ & 2,878 \\
Woman-months of use & & & & \\
\hline
\end{tabular}

TABLE 12

LOW AND HIGH ESTIMATES OF CUMULATIVE GONTINUATION RATES: ALL DEVICES, 2 YEARS OF USE, AND LOOP D, 1 TO 5 YEARS OF USE

\begin{tabular}{|c|c|c|}
\hline $\begin{array}{c}\text { Devices and } \\
\text { Years of use (Loop D) }\end{array}$ & Low & High \\
\hline $\begin{array}{l}\text { All devices } \\
\text { Loop A } \\
\text { Loop B } \\
\text { Loop C } \\
\text { Loop D } \\
\text { Small spiral } \\
\text { Large spiral } \\
\text { Small bow } \\
\text { Large bow } \\
\text { Steel ring }\end{array}$ & $\begin{array}{l}60 \cdot 4 \\
41.8 \\
47 \cdot 8 \\
55 \cdot 8 \\
54.5 \\
54 \cdot 2 \\
57 \cdot 9 \\
62 \cdot 4 \\
52 \cdot 3\end{array}$ & $\begin{array}{l}64 \cdot 8 \\
71 \cdot 3 \\
72 \cdot 1 \\
70 \cdot 4 \\
62 \cdot 1 \\
66 \cdot 2 \\
66 \cdot 3 \\
72 \cdot 2 \\
71 \cdot 1\end{array}$ \\
\hline $\begin{array}{c}\text { Loop } D \\
1 \text { year } \\
2 \text { years } \\
3 \text { years } \\
4 \text { years } \\
5 \text { years }\end{array}$ & $\begin{array}{l}70 \cdot 8 \\
55 \cdot 8 \\
46 \cdot 5 \\
40 \cdot 3 \\
36 \cdot 5\end{array}$ & $\begin{array}{l}79 \cdot 4 \\
70 \cdot 4 \\
63.9 \\
59 \cdot 2 \\
57 \cdot 5\end{array}$ \\
\hline
\end{tabular}


TABLE 13

LOWER AND UPPER CONFIDENCE LIMITS (95\%) FOR ANNUAL AND 1-YEAR GUMULATIVE RATES, BY LEVEL OF RATE AND WOMAN-MONTHS OF USE

\begin{tabular}{|c|c|c|c|c|c|c|c|c|c|c|c|c|}
\hline \multirow{2}{*}{$\begin{array}{c}\text { Rate } / 100 \\
\text { women }\end{array}$} & \multicolumn{12}{|c|}{ Woman-months of use } \\
\hline & $L L{ }^{1,}$ & ${ }_{U L}^{0}$ & & $\stackrel{00}{U L}$ & & ${ }^{00} U L$ & $L L$ & $\stackrel{00}{U L}$ & $\stackrel{24}{L L}$ & $\stackrel{00}{U L}$ & & $\stackrel{00}{U L}$ \\
\hline $\begin{array}{r}0 \cdot 0 \\
0 \cdot 1 \\
0 \cdot 2 \\
0 \cdot 5 \\
1 \cdot 0 \\
2 \cdot 0 \\
5 \cdot 0 \\
10 \cdot 0 \\
15 \cdot 0 \\
20 \cdot 0 \\
25 \cdot 0 \\
30 \cdot 0 \\
40 \cdot 0 \\
50 \cdot 0\end{array}$ & $\begin{array}{r}0 \cdot 0 \\
0 \cdot 0 \\
0 \cdot 0 \\
0 \cdot 0 \\
0 \cdot 0 \\
0 \cdot 2 \\
1 \cdot 6 \\
4 \cdot 9 \\
8 \cdot 6 \\
12 \cdot 6 \\
16 \cdot 8 \\
21 \cdot 2 \\
30 \cdot 3 \\
39 \cdot 8\end{array}$ & $\begin{array}{r}3 \cdot 7 \\
3 \cdot 9 \\
4 \cdot 1 \\
4 \cdot 6 \\
5 \cdot 5 \\
7 \cdot 1 \\
11 \cdot 3 \\
17 \cdot 7 \\
23 \cdot 6 \\
29 \cdot 2 \\
34 \cdot 7 \\
40 \cdot 0 \\
50 \cdot 3 \\
60 \cdot 2\end{array}$ & $\begin{array}{r}0 \cdot 0 \\
0 \cdot 0 \\
0.0 \\
0.0 \\
0 \cdot 1 \\
0.5 \\
2 \cdot 4 \\
6 \cdot 2 \\
10 \cdot 3 \\
14 \cdot 6 \\
19 \cdot 2 \\
23 \cdot 7 \\
33 \cdot 1 \\
42 \cdot 8\end{array}$ & $\begin{array}{r}1 \cdot 9 \\
2 \cdot 1 \\
2 \cdot 3 \\
2 \cdot 8 \\
3 \cdot 6 \\
5 \cdot 1 \\
9 \cdot 1 \\
15 \cdot 1 \\
20 \cdot 8 \\
26 \cdot 3 \\
31 \cdot 6 \\
36 \cdot 9 \\
47 \cdot 2 \\
57 \cdot 2\end{array}$ & $\begin{array}{r}0 \cdot 0 \\
0 \cdot 0 \\
0 \cdot 0 \\
0 \cdot 0 \\
0 \cdot 3 \\
1 \cdot 0 \\
3 \cdot 2 \\
7 \cdot 5 \\
11 \cdot 9 \\
16 \cdot 5 \\
21 \cdot 2 \\
26 \cdot 0 \\
35.6 \\
45.5\end{array}$ & $\begin{array}{r}0.8 \\
1.0 \\
1.2 \\
1.6 \\
2 \cdot 4 \\
3 \cdot 6 \\
7 \cdot 3 \\
13 \cdot 0 \\
18 \cdot 5 \\
23 \cdot 8 \\
29 \cdot 1 \\
34 \cdot 3 \\
44.5 \\
54.5\end{array}$ & $\begin{array}{r}0.0 \\
0.0 \\
0 \cdot 0 \\
0 \cdot 2 \\
0.4 \\
1 \cdot 2 \\
3.7 \\
8 \cdot 2 \\
12 \cdot 8 \\
17.5 \\
22 \cdot 3 \\
27 \cdot 1 \\
36.9 \\
46.8\end{array}$ & $\begin{array}{r}0.4 \\
0.6 \\
0.8 \\
1.2 \\
1.9 \\
3.1 \\
6.6 \\
12.1 \\
17.4 \\
22.7 \\
27.9 \\
33 \cdot 0 \\
43.2 \\
53.2\end{array}$ & $\begin{array}{r}0 \cdot 0 \\
0 \cdot 0 \\
0 \cdot 0 \\
0 \cdot 2 \\
0 \cdot 6 \\
1 \cdot 4 \\
4 \cdot 0 \\
8 \cdot 7 \\
13 \cdot 4 \\
18 \cdot 2 \\
23 \cdot 1 \\
28 \cdot 0 \\
37 \cdot 8 \\
47 \cdot 7\end{array}$ & $\begin{array}{r}0.2 \\
0 \cdot 4 \\
0 \cdot 6 \\
1.0 \\
1.6 \\
2 \cdot 7 \\
6 \cdot 1 \\
11 \cdot 4 \\
16.7 \\
21.9 \\
27 \cdot 0 \\
32 \cdot 1 \\
42 \cdot 2 \\
52 \cdot 3\end{array}$ & $\begin{array}{r}0 \cdot 0 \\
0 \cdot 0 \\
0 \cdot 1 \\
0 \cdot 3 \\
0 \cdot 7 \\
1 \cdot 6 \\
4 \cdot 4 \\
9 \cdot 1 \\
14 \cdot 0 \\
18 \cdot 9 \\
23 \cdot 8 \\
28 \cdot 7 \\
38 \cdot 6 \\
48 \cdot 6\end{array}$ & $\begin{array}{r}0 \cdot 1 \\
0 \cdot 3 \\
0.4 \\
0 \cdot 8 \\
1 \cdot 4 \\
2 \cdot 4 \\
5 \cdot 7 \\
10 \cdot 9 \\
16 \cdot 1 \\
21 \cdot 2 \\
26 \cdot 3 \\
31 \cdot 3 \\
41.4 \\
51 \cdot 4\end{array}$ \\
\hline
\end{tabular}

$\mathrm{LL}=$ Lower limit; UL $=$ Upper limit

pregnancy rates after re-insertion, and the removal or pregnancy rates after a first insertion.

Low and high estimates of cumulative continuation rules for Loop D for 5 years and all other devices for 2 years are shown in Table 12. In most other tables (Tables 5 to 11 ) the assumption is that pregnancies, expulsions, removals and re-insertions occur with the same frequency among women lost to follow-up as they do among those who remain under observation. The low estimates in this table are based on the assumption that all cases lost to follow-up were closed; and the high estimates, that all of these cases remained users.

The order of magnitude of sampling errors is illustrated in Table 13 for annual and 1-year cumulative rates from 0.0 to 50 per 100 women, based on samples from 1200 to 60,000 woman-months of use. The lower and upper limits shown are approximations, derived by interpolation and rounding from the tables of Mainland, Herrera \& Sutcliffe (1956). The maximum risks of over-estimating the upper limit are $2.5 \%$ each.

It is obvious that rates based on small samples, especially low rates, should be interpreted with great care, taking into account any similarities and dissimilarities in the patterns of rates for different types and sizes of IUDs. Confidence limits for $\mathrm{N}$-year cumulative rates approximate those based on the number of woman-months divided by $\mathrm{N}$ for 1-year rates.

\section{REFERENCES}

Mainland, D., Herrera, L. \& Sutcliffe, M. I. (1956) Tables for use with binomial samples. New York University College of Medicine.

Potter, R. G. (1963) Additional measures of use-effectiveness of contraception. Milbank meml Fund q. Bull. 41, 400 .

Potter, R. G. (1966) Application of life table techniques to measurement of contraceptive effectiveness. Demography, 3, 297. 
Potter, R. G. (1967) The multiple decrement life table as an approach to the measurement of useeffectiveness of contraception. The Conference of the International Union for the Scientific Study of Population, Sydney, p. 15.

TIETZE, C. (1965) Recommended procedures for the statistical analysis of clinical data on intra-uterine contraceptive devices, p. 10. National Committee on Maternal Health. New York.

TIETZE, C. (1967) Intra-uterine contraception: recommended procedures for data analysis. Studies in Family Planning, 19 (Suppl.), 1.

VIEL, B. (1966) Estudio de seguimiento de 18 meses del dispositivo intra-uterino de Lippes en mujeres fertiles de 20 a 29 anos de edad, p. 8. 